Pena Justisia: Media Komunikasi dan Kajian Hukum
Volume 18, No.1, 2019
Artikel Hasil Penelitian

\title{
AKSESABILITAS KAUM DIFABEL DALAM PERLINDUNGAN HUKUMNYA DALAM PERSPEKTIF HAK ASASI MANUSIA
}

\author{
Muhammad Miftahul Umam**, Ridwan Arifin ${ }^{* *}$ \\ ** Fakultas Hukum Universitas Negeri Semarang, Email: umammiftah99@gmail.com \\ ** Fakultas Hukum Universitas Negeri Semarang, Email: ridwan.arifin@mail.unnes.ac.id
}

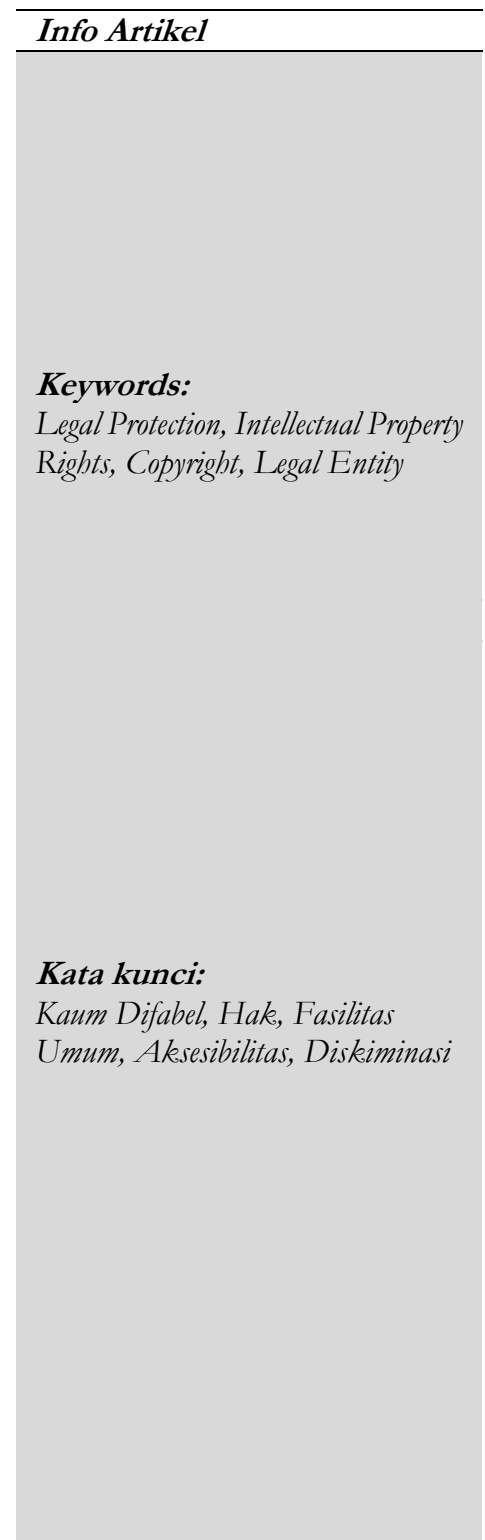

\begin{abstract}
Intellectual property rights by nature provide economic benefits to the creator or holder of copyright and also to the state. Among the European countries that are members of the Euroean Union (EU) and in America, this awareness of economic benefits has been firmly planted. In these developed countries, several economic studies have been conducted which have proven the rapid growth of copyright contribution to the national income of the country. The need to recognize, protect and reward individuals or companies for their inventions and access to their work for the benefit of humans is beginning to be felt in Indonesia. In the context of copyright ownership over anything related to intellectual property rights, the law acts and guarantees the creator to control and enjoy exclusively the results of his work and if necessary with the assistance of the state for law enforcement. The results showed that legal protection can be carried out with supervision by the government and involves legal entities that already have the authority, socializing both the creators of a work or the copyright holder of a related rights product on the importance of registering or recording the work and the copyright holder submits lawsuit to the Commercial Court.
\end{abstract}

\begin{abstract}
Abstrak
Kebebasan adalah hak asasi setiap manusia. Kebebasan dalam berfikir, berpendapat, dan kebebasan dalam menjalani kehidupan merupakan hak mutlak bagi setiap manusia yang hidup di dunia ini. Namun dalam realitanya, kebebasan tersebut tidak dapat dirasakan oleh semua orang. Salah satu diantaranya adalah seseorang yang memiliki keterbatasan fisik atau penyandang cacat. Keberadaan kaum penyandang cacat atau biasa dikenal dengan kaum difabel ini tidak dapat diingkari dan menjadi bagian dari kehidupan manusia. Penyandang cacat dapat digolongkan menjadi 3 jenis, yakni: cacat secara fisk, nonfisik, dan ganda. Pada intinya semua kelompok tersebut sama, yakni bersumber dari ketidakmampuan atau tidak berfungsinya organ-organ fisik seperti panca indra dan nonfisik. Dalam kehidupan sehari-hari para penyandang cacat ini tidak bisa merasakan kebebasan yang sesungguhnya. Bagi para penyandang cacat tidaklah mudah untuk melakukan aktivitas seperti orang normal pada umumnya. Salah satunya ketika menggunakan fasilitas umum, seperti trotoar, jembatan penyeberangan, transportasi umum dan lain sebagainya. Hal ini dikarenakan minimnya fasilitas pendukung bagi kaum difabel tersebut. Memang ada beberapa fasilitas fasilitas pendukung seperti guiding block. Namun seringkali jalurnya tertutupi oleh para pedagang kaki lima dan kondisinya juga sudah mulai kurang layak untuk digunakan. Selain kesulitan dalam menggunakan akses fasilitas umum, para penyandang cacat ini juga sering mendapat perlakuan yang bersifat diskriminatif dan pandanagan buruk dari orang lain. Padahal kaum penyandang cacat ini juga memiliki hak yang sama untuk dapat
\end{abstract}


hidup dengan layak dan bermasyarakat sebagaimana orang normal lainnya. Maka dari itu untuk mewujudkan rasa keadilan tersebut diperlukan penyediaan aksesibilitas yang layak untuk para kaum difabel agar dapat mempermudah aktivitas mereka. Dalam aspek hukum dan sosial, mereka memiliki derajat yang sama dari segi keberadaannya. Meskipun dalam beberapa kondisi dan keadaan mempunyai kekhususan tersendiri sebagai bentuk perlindungan terhadapnya.

\section{PENDAHULUAN}

Hak Asasi Manusia merupakan suatu hak yang harus dihormati dan dihargai oleh setiap manusia. Namun dalam kenyataannya masih banyak orang yang tidak memahami makna dari hak asasi tersebut. Sebagian dari masyarakat memang mengetahui pengertian dari hak asasi, namun tidak memahami makna dari hak asasi itu sendiri. Sehingga masih sering terjadi diskriminasi yang dialami oleh masyarakat di Indonesia. Contoh kasus yang pernah terjadi adalah tindakan diskriminatif yang dilakukan oleh Etihad Airways di Bandara Soekarno-Hatta kepada Dwi Ariyani, yakni seorang penyandang disabilitas asal Karanganyar, Jawa Tengah. Ia dipaksa turun dari kabin pesawat oleh maskapai kru penerbangan tersebut. Sehingga ia gagal terbang dari Bandara Soekarno-Hatta, Banten menuju Jenewa, Swiss pada bulan April 2016 lalu. Dengan kejadian tersebut, akhirnya Etihad Airways dijatuhi hukuman denda ganti rugi sebesar Rp.500 juta kepada Dwi Ariyani ${ }^{1}$. Dalam Pasal 28 I ayat (2) Undang-Undang Dasar Republik Indonesia Tahun 1945, menjelaskan bahwa setiap orang berhak bebas dari perlakuan diskriminatif atas dasar apapun dan berhak mendapatkan perlindungan terhadap perlakuan diskriminatif tersebut. Dengan demikian, dapat dikatakan bahwa setiap orang berhak mendapatkan perlindungan dari tindakan diskriminatif. Maka dari itu Negara wajib memberikan perlindungan kepada mereka yang mendapat tindakan diskriminatif tersebut.

Pasal 34 Ayat (3) Undang-Undang Dasar Republik Indonesia Tahun 1945 menyatakan bahwa Negara mempunyai tanggung jawab atas penyediaan fasilitas kesehatan dan fasilitas pelayanan umum yang layak. Artinya, pemerintah mempunyai kewajiban untuk menyediakan aksesibilitas pelayanan umum yang memadai dan layak bagi masyarakat. Hal ini dimaksukan untuk mewujudkan kesamaan kesempatan dalam segala aspek kehidupan dan penghidupan bagi penyandang disabilitas. Pemerintah juga harus memberikan perlindungan hukum terhadap kedudukan, hak, kewajiban, dan peran para penyandang disabilitas karena keterbatasan mereka, baik dalam aspek fisik atau lebih khususnya panca indra maupun mental atau psikologis. Salah satu aspek terpenting manusia dalam menunjang aktivitasnya adalah panca indra. Panca indra dianalogikan seperti jendela bagi jiwa. Konsep pengetahuan dan gambaran mengenai suatu objek eksternal masuk kedalam pikiran manusia melalui panca indra ${ }^{2}$. Namun diantara semua manusia yang lahir di dunia ini terkadang memiliki keadaan yang berbeda dengan manusia normal pada umumnya. Ada yang mengalami kelainan baik fisik maupun mental atau biasa disebut dengan cacat. Penyandang cacat atau yang biasa kita kenal dengan kaum difabel atau penyandang disabilitas merupakan bebrapa istilah yang ditujukan kepada seseorang yang memiliki kondisi atau kemampuan yang berbeda dibandingkan dengan orang normal pada umumnya. Terurama dalam hal fisik ${ }^{3}$.

Penyandang Cacat dalam prespektif ilmu sosial secara umum dapat dikelompokkan menjadi 3 jenis, yakni:

1. Kelainan fisik (tunanetra, tunarungu, tunawicara dan tunadaksa)

\footnotetext{
${ }^{1}$ BBC Indonesia, 2017, Usir Penyandang Disabilitas di Bandara Soekarno-Hatta, Etihad dibukum Rp500 Juta, (diakses dari https://www.google.com/amp/s/www.bbc.com/indonesia/amp/indonesia-42220263 pada tanggal 07 Desember 2018).

2 Kadar M. Yusuf, 2003, Indera Manusia Menurut Al-Qur'an dan Psikologi: Suatu Kajian Perbandingan, (Laporan Penelitian: Universitas Negeri Sultan Syarif Kasim Riau), hlm. 6.

${ }^{3}$ Nur Khalis Setiawan, 2012, Pribumisasi Al-qur'an (Yogyakarta: Kaukaba), hlm. 75.
} 
2. Kelainan nonfisik (tunagrahita, tunalaras dan austis)

3. Kelainan ganda yaitu mereka yang memilki kelainan lebih dari satu jenis ${ }^{4}$.

Diskusi mengenai kelompok tersebut diperkirakan muncul pada dasawarsa terakhir. Hal tersebut dilatarbelakangi oleh kenyataan bahwa jumlah mereka yang lumayan banayak. Maka dari itu perlu dilakukan sebuah kajian mengenai keberadaan kelompok tersebut. Berdasarkan data dari WHO (Badan Kesehatan Dunia), ILO (International Labour Organization) dan Bank Dunia, menyatakan bahwa pada tahun 2016 jumlah difabel mencapai satu miliyar orang atau 15 persen dari populasi dunia. serta terdapat 785 juta penyandang cacat yang telah masuk dalam usia kerja. Kemudian BPS atau Badan Pusat Statistik (2016), menerbitkan Survei Ketenagakerjaan Nasional (Sakernas).

Kepala Tim Riset LPEM FEB Universitas Indonesia, Alin Halimatussadiah menjelaskan bahwa jumlah penyandang disabilitas di Indonesia mencapai 12,15 persen. Jumlah penyandang disabilitas di Indonesia lebih banyak didominasi oleh kaum perempuan, yakni dengan persentase 53,37 persen dan laki-laki 46,63 persen. Kemudian berdasarkan tingkat keparahannya, penyandang disabilitas tingkat sedang sebanyak 10,29 persen dan kategori berat sebanyak 1,8 persen. Sementara untuk jumlah individu atau persentase populasi penyandang disabilitas provinsi di Indonesia antara 6,41 persen hingga 18,5 persen. Tiga provinsi yang memiliki tingkat prevelensi paling tinggi adalah Sumatra Barat, Nusa Tenggara Timur, dan Sulawesi Selatan. Dalam hal pendidikan, dari 12,15 persen penyandang disabilitas di Indonesia, 45,74 persennya tidak pernah atau tidak lulus Sekolah dasar (SD). Sangat jauh berbeda apabila dibandingkan dengan non-penyandang disabilitas yang berkesempatan menempuh pendidikan Sekolah Dasar (SD) ke atas dengan persentase sebanyak 87,31 persen. Hal ini dimaksudkan untuk mengetahui kondisi penyandang disabilitas di pasar tenaga kerja Indonesia ${ }^{5}$.

Disamping dengan Undang-Undang tentang penyandang disabilitas, pemerintah juga telah melakukan upaya melindungi hak penyandang disabilitas melalui berbagai peraturan Perundangundangan, antara lain: peraturan yang mengatur masalah ketenagakerjaan, kesehatan, pendidikan, kesejahteraan sosial, lalu lintas dan angkutan jalan, perkereta apian, pelayaran, dan penerbangan. Peraturan Perundang-undangan tersebut memberikan jaminan kepada Penyandang disabilitas agar mendapatkan kemudahan (aksesibilitas) ${ }^{6}$. Pembangunan transportasi publik merupakan salah satu pelayanan yang disediakan oleh Pemerintah untuk masyarakat. dalam pembangunannya harus dibuat dengan memenuhi standar agar semua kalangan masyarakat dapat menggunakannya. Namun terkadang masih sering terdapat kalangan masyarakat belum dapat menggunakan aksesibilitas publik tersebut secara maksimal dan optimal, seperti misalnya seseorang yang memiliki kebutuhan khusus yaitu Penyandang Disabilitas. Dalam Pasal 41 ayat (2) Undang-Undang Nomor 39 Tahun 1999 tentang Hak Asasi Manusia menyatakan bahwa Setiap penyandang cacat, orang yang berusia lanjut, wanita hamil, dan anak-anak mempunyai hak untuk memperoleh kemudahan dan perlakuan khusus. Penyandang Disabilitas merupakan seseorang yang mempunyai keterbatasan fisik ataupun mental sehingga memerlukan bantuan sarana dan prasarana khusus dalam menjalankan aktivitasnya. Penyandang Disabilitas merupakan salah satu orang yang tidak bisa lepas dari bantuan orang lain. Penjelasan Pasal 18 ayat (1) dan ayat (2) Undang-Undang Nomor 39 Tahun 1999 tentang Hak Asasi Manusia menjelaskan bahwa hak pelayanan publik untuk Penyandang Disabilitas meliputi hak:

\footnotetext{
${ }^{4}$ Akhmad Sholeh, 2015, "Islam dan Penyadang Disabilitas: Telaah Hak Aksesibilitas Penyandang Disabilitas dalam Sistem Pendidikan di Indonesia", Jurnal Palastren, Volume 8, Nomor 2, 2015, hlm. 303.

5 Republika.co.id. 2016. Indonesia Miliki 12 Persen Penyandang Disabilitas. (diakses dari https://www.google.com/amp/s/m.republika.co.id/amp/oi9ruf384 pada tanggal 05 Desember 2018).

${ }^{6}$ H. Muladi, 2005, Hak. Asasi Manusia Hakekat, Konsep \& Implikasinya Dalam Perspektif Hukum Dan Masyarakat (Bandung: PT Refika Aditama), hlm. 255.
} 
1. Memperoleh akomodasi yang layak dalam pelayanan publik secara optimal,wajar, bermartabat tanpa diskriminasi.

2. Pendampingan, penerjemahan, dan penyediaan fasilitas yang mudah diakses di tempat layanan publik tanpa tambahan biaya.

Banyak sekali fasilitas umum yang disediakan oleh pemerintah untuk memudahkan kepentingan masyarakat. Salah satu diantaranya adalah Bus Kota. Bus Kota merupakan transportasi umum yang menyediakan aksesibilitas bagi penyandang disabilitas. Seperti misalnya landasan (ramp) pada halte bagi penyandang disabilitas yang menggunakan kursi roda. Namun, Bus Kota ternyata tidak dapat dengan mudah diakses oleh penyandang disabilitas dikarenakan bus tersebut menggunakan high floor (pintu yang tinggi) dan ketika ada penumpang berkursi roda ingin naik harus dibantu untuk diangkat masuk ke dalam bus karena ada jarak antara pintu bus dengan bibir peron/halte. Ini dikarenakan bus tidak bisa berbatasan dengan halte ${ }^{7}$. Kemudian landasan (ramp) pada halte yang memiliki ketinggian yang terlalu curam mengakibatkan penyandang disabilitas yang menggunakan kursi roda susah untuk menggunakan halte tersebut.

Selain keterbatasan dalam menggunakan fasilitas umum, para penyandang disabilitas juga kerap kali mendapatkan perlakuan yang tidak mengenakkan serta pandangan negatif dari orang yang berada disekitarnya. Tindakan bulliying, pengucilan, serta penolakan saat melamar pekerjaan sering mereka alami karena keterbatasan yang mereka miliki. Bahkan yang lebih memprihatinkan lagi adalah praktik diskriminasi kepada penyandang disabilitas tersebut juga biasa dilakukan dilingkungan sekolah yang notabenenya menjadi basis dalam mengkampanyekan ramah kaum difabel $^{8}$. Meskipun dunia sudah mulai memperhatikan keberadaan kelompok ini dengan ditetapkannya hari Penyandang Disabilitas Sedunia pada tanggal 3 Desember, namun karena minimnya sosialisasi menyebabkan peringatan tersebut kurang dikenal oleh masyarakat luas.

\section{PEMBAHASAN}

\section{Perlindungan dan Hak Kaum Difabel dalam Perspektif Hak Asasi Manusia}

Istilah Difabel berasal dari bahasa Inggris, yakni Difable (Differently able, Different ability, Diffrently abled people), yang berarti seseorang dengan kemampuan berbeda,. Dalam KBBI, difabel memiliki arti penyandang cacat. Dengan demikian, istilah difabel ini dipakai untuk menunjuk kepada seseorang yang menyandang cacat. Istilah difabel dipakai untuk menggantikan kata disabilitas yang oleh para aktivis gerakan sosial pada tahun 1990-an dianggap diskriminatif dan mengandung pandangan negatif. Istilah Disabilitas berasal dari bahasa Inggris “Dis able, Disability” yang berarti ketidakmampuan. The Social Work Dictionary mendefinisikan Disability sebagai ketidakmampuan seseorang untuk melakukan sesuatu yang mampu dilakukan oleh orang lain sebagai akibat dari kecacatan fisik yang dimilikinya secara permanen atau temporer'. Penggunaan istilah ini menunjuk kepada konsekuensi fungsional sebagai akibat dari kerusakan tubuh seseorang. Misalnya, seseorang yang mengalami perumbuhan tulang kaki yang tidak normal karena penyakit polio. Ia tidak bisa beraktivitas dengan bebas apabila tidak dibatu dengan kursi roda atau kaki palsu. Dengan demikian, penggunaan istilah Difabel ini dimaksudkan untuk menghapus pandangan negatif dan perlakuan diskriminatif masyarakat terhadap para penyandang cacat. Kemudian istilah tersebut dipopulerkan oleh seorang aktivis pergerakan sosial pada tahun 1995 bernama Mansour Fakih dalam pengertian kemampuan fisik yang berbeda ${ }^{10}$.

\footnotetext{
7 Nanda, Trans Jogja Belum Ramah Difabel, (diakses dari http://liputan.tersapa.com/transjogja-belum-ramahdifabel/ pada tanggal 07 Desember 2018).

${ }^{8}$ Khairunnas Jamal, Nasrul Fatah, dan Wilaela, 2017, “Eksistensi Kaum Difabel dalam Prespektif Al-Qur'an”, Jurnal Ushuluddin, Volume 25, Nomor 2, 2017, hlm. 222.

${ }^{9}$ Hasanah, A to Z Kamus Psikologi Super Lengkap (Yogyakarta: Andi Offset), hlm. 83.

${ }^{10}$ Mansour Fakih, 2004, Kesetaraan Hak Penyandang Cacat (Yogyakarta: Kaukaba), hlm. 168-169.
} 
Kemudian berdasarkan Pasal 1 Ayat (1) Undang-Undang Republik Indonesia Nomor 4 Tahun 1997 tentang Penyandang Cacat, mendefinisikan Penyandang Cacat sebagai seseorang yang mengalami kelainan fisik atau mental sehingga mengganggu atau menghambat dirinya dalam beraktivitas sebagaimana yang dilakukan oleh orang normal. Definisi ini dianggap cukup representatif untuk mewakili gambaran masyarakat umum terhadap penyandang cacat. Dan Pasal 1 Ayat (1) Undang-Undang Nomor 8 Tahun 2016 tentang penyandang disabilitas mendefinisikannya sebagai setiap orang yang mengalami keterbatasan fisik, intelektual, mental, atau sensorik dalam jangka waktu lama sehingga berintraksi dengan lingkungan mengalami hambatan dan kesulitan untuk berpartisipasi secara penuh dengan warganegara lainnya berdasarkan persamaan hak""11.

Terdapat banyak istilah yang digunakan untuk menyebut penyandang cacat. Dan masing-masing istilah tersebut mempunyai kepentingan tersendiri dalam penyebutannya, dengan pertimbangan penggunaannya. Antara lain: Penyandang Cacat. Istilah ini berasal dari 2 kata "penyandang dan cacat". Menurut KBBI, kata penyandang berasal dari kata "Sandang" yang berarti orang yang menderita. Dan kata cacat yang berarti kekurangan yang mengakibatkan nilai atau mutunya menjadi kurang baik atau kurang sempurna. yang dimaksud terdapat pada tubuh, benda, batin atau akhlak. Kemudian lecet yang menyebabkan keadaannya menjadi kurang baik atau kurang sempurna, cela dan aib. Penyandang Ketunaan. Istilah ini berasal dari bahasa jawa kuno "Tuna" yang memilki arti rusak atau rugi. Menurut KBBI, kata tuna berarti luka, rusak, kurang atau tidak memilki. Kata ini diperkenalkan sekitar awal tahun 1990-an. Penggunaan kata ini merujuk kepada kekkurangan yang dimiliki oleh seseorang dalam artian fungsi organ tubuhnya. Contohnya, istilah tunarungu, tunanetra, tunadaksa dan tunagrahita. Penggunaan kata tuna ini dimaksudkan untuk memperhalus kata cacat, karena kata tersebut dianggap lebih menghormati martabat penyandang cacat. Kemudian dalam perkembangan selajutnya, kata tuna ini digunakan juga sebagai istilah pengganti kekurangan nonorganik seperti istilah tunalaras, tunawisma dan tunasusila.

Orang Berkebutuban Khusus (Person With Special Needs). Frieda Mangunsong mengartikan orang berkebutuhan khusus sebagai orang yang fungsi kemanusiaannya berbeda dimensi secara signifikan. Yakni secara fisik, psikologis, kognitif atau sosial mengalami hambatan dalam mencapai tujuan. Misalnya tuli, buta, gangguan bicara, cacat tubuh, cacat mental atau gangguan emosional. Selain itu, seseorang yang memiliki intelegensi yang sangat tinggi juga dapat digolongkan sebagai orang berkebutuhan khusus atau luar biasa karena membutuhkan penanganan yang terlatih dari tenaga profesional ${ }^{12}$. Jadi, penggunaan istilah orang yang berkebutuhan khusus memiliki makna yang cukup luas yakni seseorang yang membutuhkan penanganan khusus baik karena kekurangan maupun kelebihan yang dimilikinya. Istilah ini banyak digunakan dalam bidang kependidikan.

Terdapat banyak istilah yang digunakan untuk menggambarkan seorang penyandang cacat. Dan masing-masing memiliki makna tersendiri. Namun dari semua istilah yang digunakan untuk menunjuk pada penyandang cacat tersebut memiliki inti kesimpulan yang sama bahwa penyandang cacat adalah seseorang dengan kemungkinan cukup besar dalam menghadapi kesulitan dalam menjalankan aktivitas sehari-hari. Maka dari itu, mereka membutuhkan perlakuan, pelayanan serta informasi yang tepat sehingga potensi yang terdapat dalam diri mereka dapat berkembang secara optimal.

Setiap manusia memiliki hak masing-masing bahkan sejak dari lahir. Salah satunya adalah hak asasi manusia. Hak tersebut tidak hanya dimiliki oleh orang yang sempurna saja secara fisik, namun juga mereka yang memiliki kondisi kurang sempurna dibandingkan dengan manusia pada umumnya atau biasa kita kenal dengan cacat. Sebagai bentuk perlindungan hukum terhadap pemenuhan hak

${ }^{11}$ Ismail Shaleh, 2018, "Implementasi Pemenuhan Hak Bagi Penyandang Disabilitas Ketenagakerjaan”, Kanun Jurnal Ilmu Hukum, Volume 20, Nomor 1, 2018, hlm. 64.

12 Dewi Pandii, 2013, Sudabkah Kita Ramah Pada Anak Special Needs? (Jakarta: PT. Elex Media Komputindo), hlm.2. 
asasi manusia di Indonesia khususnya, untuk mendapatkan pekerjaan yang layak bagi kaum disabilitas, maka diperlukan seperangkat peraturan hukum yang adil dan tegas dalam mengatur, aparat negara yang sigap, dan pro disabilitas serta masyarakat yang terbuka terhadap isu disabilitas ${ }^{13}$. Kesempatan untuk mendapatkan kesamaan kedududukan, hak dan kewajiban bagi penyandang disabilitas hanya dapat diwujudkan apabila tersedia aksesibilitas, yakni suatu kemudahan bagi penyandang cacat untuk mencapai kesamaan kesempatan dalam memperoleh kesamaan kedudukan, hak, dan kewajiban. Maka dari itu, perlu diadakan upaya penyediaan aksesibilitas bagi penyandang cacat.

Dengan upaya tersebut diharapkan penyandang cacat ini dapat berintegrasi secara total dalam mewujudkan tujuan pembangunan nasional serta meningkatkan kesejahteraan sosial, khususnya kepada penyandang cacat. Peningkatan kesejahteraan sosial dilaksanakan melalui kesamaan kesempatan bagi penyandang cacat yang pada hakikatnya menjadi tanggung jawab bersama pemerintah, masyarakat, keluarga dan penyandang cacat itu sendiri. Oleh sebab itu, diharapkan semua unsur tersebut dapat berperan secara aktif untuk dapat mewujudkannya. Dengan kesamaan kesempatan tersebut diharapkan para penyandang disabilitas dapat menjalankan perannya untuk melaksanakan fungsi sosialnya dalam artian mampu berintegrasi melalui komunikasi dan interaksi secara wajar dalam menjalani hidup bermasyarakat ${ }^{14}$.

\section{Hak atas Kaum Difabel dalam Aturan Perundang-Undangan Nasional}

Pasal 27 ayat 2 Undang-Undang Dasar Republik Indonesia Tahun 1945 menegaskan bahwa setiap warga negara Indonesia berhak atas pekerjaan dan penghidupan yang layak. Makna dari pasal tersebut adalah bahwa negara mempunyai tanggung jawab terhadap hak konstitutional seluruh warganegaranya tidak terkecuali penyandang disabilitas sekalipun ${ }^{15}$. Penyandang disabilitas harus mendapatkan perlindungan. Berdasarkan Pasal 1 Ayat 5 Undang-Undang Nomor 8 Tahun 2016 menjelaskan bahwa perlindungan terhadap penyandang disbilitas merupakan upaya yang secara sadar dilakukan untuk melindungi, mengayomi dan memperkuat hak penyandang disabilitas. Sebagai bagian dari warganegara, maka sepantasnya penyandang disabilitas mendapatkan perlakuan khusus sebagai upaya perlindungan dari keretanan mereka terhadap tindakan diskriminasi dan pelanggaran hak asasi manusia. Perlakuan khusus tersebut dipandang sebagai usaha maksimalisasi penghormatan, pemajuan, perlindungan dan pemenuhan hak asasi manusia secara universal ${ }^{16}$.

Berjalan dan menaiki eskalator bagi kebanyakan orang memang terlihat sepele. Namun, aktivitas tersebut bisa menjadi masalah bagi seorang penyandang cacat. Apalagi kalau tidak ada fasilitas khusus yang disediakan untuk kaum difabel ini. Masalah minimnya akses khusus di tempat umum sudah menjadi menu sehari-hari bagi penyandang cacat. Memang sudah terdapat beberapa tempat umum yang memperhatikan kebutuhan bagi para penyandang cacat, namun hanya sebagian kecil tempat yang sudah menyediakan akses khusus tersebut. Misalnya para penyandang cacat tuna netra, mereka memerlukan keterangan dalam bentuk huruf braile dan guiding block atau tanda pemandu sebagai penanda tepi trotoar atau tangga. Kemudian penyandang tuna daksa, mereka memerlukan kekuasaan akses yang memudahkan mereka dalam bergerak. Sementara bagi

\footnotetext{
${ }^{13}$ Jazim Hamidi, 2016, "Perlindungan Hukum Terhadap Disabilitas Dalam Memenuhi Hak Mendapatkan Pendidikan Dan Pekerjaan”, Jurnal Hukum Ius Quia Iustum, Volume 23, Nomor 4, 2016.

${ }^{14}$ Suhartoyo, 2014, "Perlindungan Hukum Terhadap Pekerja/Buruh Penyandang Disabilitas Di Indonesia", Jurnal Masalah-Masalab Hukum, Volume 43, Nomor 4, 2014, hlm. 472.

15 Riska Maulinda, Dahlan, dan M. Nur Rasyid, 2016, "Perlindungan Hukum Bagi Pekerja Kontrak Waktu Tertentu Dalam Perjanjian Kerja”, Kanun Jurnal Ilmu Hukum, Volume 18, Nomor 3, 2016, hlm. 337.

${ }^{16}$ Budiyono, Muhtadi, dan Ade Arif Firmansyah, 2015, "Dekontruksi Urusan Pemerintahan Konkuren Dalam UndangUndang Pemerintahan Daerah”, Kanun Jurnal Ilmu Hukum, Nomor 67, Tahun XVII, 2015, hlm. 419.
} 
penyandang tuna rungu, mereka membutuhkan teks tertulis seperti teks berjalan atau bahasa isyarat untuk mengompensasi kekurangan mereka dalam pendengaran ${ }^{17}$.

Terkait dengan isu aksesibilitas untuk penyandang disabilitas, Indonesia telah memiliki regulasi nasional, diantaranya Peraturan Menteri Pekerjaan Umum Nomor 3 Tahun 2006 tentang Pedoman Teknis Fasilitas dan Aksesibilitas pada Bagunan Gedung dan Lingkungan ${ }^{18}$. Presiden Republik Indonesia telah mendorong pemerintah daerah untuk menyediakan fasilitas umum yang ramah bagi para penyandang disabilitas atau difabel. Selain itu juga Presiden akan mengundang rekan-rekan penyandang disabilitas untuk berdiskusi mengenai hal tersebut. Pada saat presiden melakukan kunjungan ke kompleks Gelora Bung Karno Senayan (16/10/2018) lalu untuk meninjau secara langsung kondisi fasilitas umum untuk penyandang difabel, ia mengklaim bahwa pengerjaannya sudah selesai sekitar 80 persen $^{19}$.

Berdasarkan apa yang telah disebutkan sebelumnya, bahwa pentingnya aksesibilitas bagi penyandang disabilitas adalah untuk menjamin kemandirian dan partisispasi mereka dalam segala bidang kehidupan di masyarakat. Diskursus aksesibilitas memiliki makna dan cakupan yang lebih luas, bukan hanya terkait dengan bangunan atau fasilitas publik, seperti pasar, gedung pemerintah atau sarana transportasi, namun juga pada pelayanan publik secara umum. Misalnya pelayanan kesehatan, pendidikan, hukum dan lain-lain ${ }^{20}$.

Kemudian upaya yang juga dilakukan untuk memenuhi hak bagi penyandang disabilitas dalam hal kependidikan. Yakni dengan berkoordinasi dan bekerjasama dengan dinas-dinas setempat seperti dinas sosial, dinas pendidikan, dan instansi terkait untuk mensosialisasikan anak disabilitas melalui PKK, Kepala Sekolah umum, kecamatan, Pemilik Sosial Kecamatan mohon untuk menghimbau dan menginformasikan kepada masyarakat luas apabila ada anak yang menyandang disabilitas untuk bisa disekolahkan. Namun upaya pemenuhan hak bagi penyandang disabilitas masih banyak kendala yang di hadapi, misalnya masih kurangnya tenaga pendidik, kondisi keuangan masyarakat khususnya yang memiliki anak penyandang disabilitas, sehingga lebih memilih untuk tidak menyekolahkan anaknya, dan terkadang juga ada orangtua yang tidak mau menyekolahkan anaknya karena merasa malu memiliki anak menyandang disabilitas ${ }^{21}$.

Setiap manusia yang lahir di dunia ini memiliki hak yang harus diharus dihormati dan dihargai oleh sesama manusia lainnya. Tidak semua manusia yang lahir didunia ini terlahir dengan fisik yang normal. Adapula manusia yang terlahir dengan kondisi fisik yang kurang sempurna. Tidak hanya fisik, namun terkadang ada juga manusia yang terlahir dengan kondisi mental yang lemah atau biasa dikenal dengan cacat mental. Mereka yang terlahir dengan kondisi fisik maupun nonfisik yang kurang sempurna seperti yang dimiliki manusia pada umumnya biasa dikenal dengan kaum difabel. penyandang cacat atau difabel merupakan seseorang dengan kelainan mental atau fisik. Kelainan tersebut dapat menjadi hambatan atau gangguan bagi dirinya dalam melakukan aktivitas. Kaum difabel juga memiliki hak yang harus dilindungi sebagaimana manusia normal pada umumnya. Namun karena keterbatasan yang mereka miliki maka adapula hak khusus bagi mereka yang harus kita hargai dan lindungi.

17 Liputan6.com, 2007, Fasilitas Bagi Penyandang Cacat Masih Minim (diakses dari https://www.google.ae/amp/s/m.liputan6.com/amp/151566/fasilitas-bagi-penyandang-cacat-masih-minim pada tanggal 07 Desember 2018).

${ }^{18}$ Slamet Tohari, 2014, "Pandangan Disabilitas dan Aksesibilitas Fasilitas Publik bagi Penyandang Disabilitas di Kota Malang”, Indonesian Journal Of Disability Studies, Volume 1, Issue 1, 2014, hlm. 29.

${ }^{19}$ Republika.co.id, 2018, Presiden Dorong Pemda Sediakan Fasilitas Umum Ramah Difabel (diakses dari https://www.google.nl/amp/s/m.republika.co.id/amp/pgocfl428 pada tanggal 07 Desember 2018).

${ }^{20}$ M. Syafi'ie, 2014, "Pemenuhan Aksesibilitas Bagi Penyandang Disabilitas", Jurnal Inklusi, Volume 1, Nomor 2, 2014, hlm. 273.

${ }^{21}$ Eta Yuni Lestari, Slamet Sumarto dan Noorochmat Isdaryanto, 2017, Pemenuhan Hak Bagi Penyandang Disabilitas Di Kabupaten Semarang Melalui Implementasi Convention On The Rights Of Persons With Disabillities (CPRD) Dalam Bidang Pendidikan, INTEGRALISTIK, Nomor 1, Tahun XXVIII/2017, hlm. 5. 


\section{Kesimpulan}

Dalam Pasal 41 ayat (2) Undang-Undang Nomor 39 Tahun 1999 tentang Hak Asasi Manusia menyatakan bahwa Setiap penyandang cacat, orang yang berusia lanjut, wanita hamil, dan anakanak, berhak memperoleh kemudahan dan perlakuan khusus. Terdapat potensi masalah yang cukup besar bagi penyandang cacat. Contohnya saat menggunakan fasilitas umum seperti trotoar, halte dan lain-lain. Penyandang cacat tuna netra, mereka memerlukan keterangan dalam bentuk huruf braile dan guiding block atau tanda pemandu sebagai penanda tepi trotoar atau tangga. Kemudian penyandang tuna daksa, mereka memerlukan kekuasaan akses yang memudahkan mereka dalam bergerak. Sementara bagi penyandang tuna rungu, mereka membutuhkan teks tertulis seperti teks berjalan atau bahasa isyarat untuk mengompensasi kekurangan mereka dalam pendengaran. Dengan keterbatasan yang mereka memiliki membuat mereka sulit menggunakan fasilitas-fasilitas tersebut. Maka dari itu mereka memerlukan perlakuan, pelayanan serta informasi yang tepat, dengan hal tersebut maka potensi yang mereka miliki dapat berkembang secara optimal. Untuk mengatasi hal tersebut, pemerintah telah berupaya dengan membuat peraturan perundang-undangan untuk melindungi hak-hak kaum difabel. Kemudian Presiden Republik Indonesia juga senantiasa mendorong pemerintah daerah untuk menyediakan fasilitas umum yang ramah bagi para penyandang disabilitas atau difabel. Selain itu juga Presiden akan mengundang rekan-rekan penyandang disabilitas untuk berdiskusi mengenai hal tersebut. Namun masih terdapat kendala, salah satunya adalah masalah biaya. Pemeritah daerah mengeluhkan penyediaan fasilitas khusus untuk difabel karena dirasa biaya untuk pembangunan kurang. Dan apabila dipaksakan maka akan menggangu anggaran untuk keperluan lainnya.

\section{REFERENCES}

Balenina, Chintami Dian Partisipasi Masyarakat dalam Pengelolaan Desa Sampah Mandiri di Desa Kalisoro, Tawangmangu, Kabupaten Karanganyar, Jurnal Bestuur Vol.VII, Issue.1, Agustus, 2019.

Budiyono, Muhtadi, dan Ade Arif Firmansyah. (2015). "Dekontruksi Urusan Pemerintahan Konkuren Dalam Undang-Undang Pemerintahan Daerah", Kanun Jurnal Ilmu Hukum, Nomor 67, Tahun XVII, 2015.

Estikomah, Solikah Ana Aspek Hukum Import Sampah Plastik, Jurnal Bestuur Vol.VII, Issue.2, December, 2019

Fakih, Mansour. (2004). Kesetaraan Hak Penyandang Cacat. Yogyakarta: Kaukaba.

Hamidi, Jazim. (2016). "Perlindungan Hukum Terhadap Disabilitas Dalam Memenuhi Hak Mendapatkan Pendidikan Dan Pekerjaan", Jurnal Hukum Ius Quia Iustum, Volume 23, Nomor 4, 2016.

Husamah. A to Z Kamus Psikologi Super Lengkap. Yogyakarta: Andi Offset.

Handayani, I Gusti Ayu Ketut Rachmi, Lego Karjoko, dan Abdul Kadir Jaelani, Model Pelaksanaan Putusan Mahkamah Konstitusi yang Eksekutabilitas Dalam Pengujian Peraturan PerundangUndangan di Indonesia, Jurnal Bestuur Vol.VII, Issue.1, Agustus, 2019.

Jamal, Khairunnas, Nasrul Fatah dan Wilaela. (2017). "Eksistensi Kaum Difabel Dalam Prespektif Al-Qur'an", Jurnal Ushuluddin, Volume 25, Nomor 2, 2017.

Lestari, Eta Yuni, Slamet Sumarto dan Noorochmat Isdaryanto. (2017). "Pemenuhan Hak Bagi Penyandang Disabilitas Di Kabupaten Semarang Melalui Implementasi Convention On The Rights Of Persons With Disabillities (CPRD) Dalam Bidang Pendidikan", INTEGRALISTIK, Nomor 1, Tahun XXVIII/2017

Maulinda, Riska, Dahlan, dan M. Nur Rasyid. (2016). "Perlindungan Hukum Bagi Pekerja Kontrak Waktu Tertentu Dalam Perjanjian Kerja”, Kanun Jurnal Ilmu Hukum, Volume 18, Nomor 3, 2016, 
Muladi, H. (2005). Hak Asasi Manusia Hakekat, Konsep \& Implikasinya Dalam Perspektif Hukum Dan Masyarakat. Bandung: PT Refika Aditama.

Pandji, Dewi. (2013). Sudabkah Kita Ramah Pada Anak Special Needs?. Jakarta: PT. Elex Media Komputindo.

Pratiwi, Ayu Dian \& Pius Triwahyudi, Jaminan Perlindungan yang Berkeadilan bagi Tenaga Kerja Difabel Akibat Kecelakaan Kerja, Jurnal Bestuur Vol.VII, Issue.2, December, 2019.

Setiawan. Nur Khalis. (2012). Pribumisasi al-Qur'an. Yogyakarta: Kaukaba.

Shaleh, Ismail. (2018). "Implementasi Pemenuhan Hak Bagi Penyandang Disabilitas Ketenagakerjaan”, Kanun Jurnal Ilmu Hukum, Volume 20, Nomor 1, 2018.

Sholeh, Akhmad. (2015). "Islam dan Penyandang Disabilitas: Telaah Hak Aksesibilitas Penyandang Disabilitas dalam Sistem Pendidikan di Indonesia", Jurnal Palastren, Volume 8, Nomor.2, 2015.

Suhartoyo. (2014). "Perlindungan Hukum Terhadap Pekerja/Buruh Penyandang Disabilitas Di Indonesia", Jurnal Masalab-Masalah Hukum, Volume 43, Nomor 4, 2014

Syafi'ie, M. (2014). "Pemenuhan Aksesibilitas Bagi Penyandang Disabilitas", Jurnal Inklusi, Volume 1 , Nomor 2, 2014

Tohari, Slamet. (2014). "Pandangan Disabilitas dan Aksesibilitas Fasilitas Publik bagi Penyandang Disabilitas di Kota Malang", Indonesian Journal Of Disability Studies, Volume 1, Issue 1, 2014.

Yusriando, Konstruksi Sistem Jaminan Sosial Nasional Bidang Kesehatan, Jurnal Bestuur Vol.VII, Issue.2, December, 2019.

Yusuf, Kadar M. (2003). "Indera Manusia Menurut al-Qur'an dan Psikologi; Suatu Kajian Perbandingan". (Laporan Penelitian: Universitas Negeri Sultan Kasim Riau).

Liputan6.com. (2007). Fasilitas Bagi Penyandang Cacat Masih Minim. (diakses dari https://www.google.ae/amp/s/m.liputan6.com/amp/151566/fasilitas-bagi-penyandangcacat-masih-minim pada tanggal 07 Desember 2018).

Nanda, Trans Jogja Belum Ramah Difabel, (diakses dari http://liputan.tersapa.com/transjogja-belumramahdifabel/ pada tanggal 07 Desember 2018).

Republika.co.id. (2016). Indonesia Miliki 12 Persen Penyandang Disabilitas. (diakses dari https://www.google.com/amp/s/m.republika.co.id/amp/oi9ruf384 pada tanggal 05 Desember 2018).

Republika.co.id. (2018). Presiden Dorong Pemda Sediakan Fasilitas Umum Ramah Difabel (diakses dari https://www.google.nl/amp/s/m.republika.co.id/amp/pgocfl428 pada tanggal 07 Desember 2018). 